\title{
Combined vitamin A and E therapy prevents retinal electrophysiological deterioration in abetalipoproteinaemia
}

\author{
SALIM BISHARA, ${ }^{1}$ SAUL MERIN,${ }^{1}$ MICHAEL COOPER,${ }^{2}$ EYOB AZIZI, ${ }^{3}$ \\ GEORGES DELPRE, AND RICHARD J. DECKELBAUM ${ }^{4}$
}

\begin{abstract}
From the 'Department of Ophthalmology, Hadassah University Hospital, Jerusalem; the ${ }^{2}$ Department of Paediatrics B, Kaplan Hospital, Rehovot; the ${ }^{3}$ Department of Paediatrics, Asaf Harofe Hospital, Zerifin, and the ${ }^{4}$ Department of Paediatrics and Gastroenterology, Hadassah University Hospital, Jerusalem, Israel
\end{abstract}

SUMMARY Eight patients with abetalipoproteinaemia had the typical ocular, systemic, and laboratory findings of this disease. Combined therapy with vitamins A and E was administered, starting as early as the first day of life and as late as $\mathbf{2 6}$ years of age. The patients were followed up for 2-6 years. Electroretinography was undertaken in all cases and electrooculography in some. After initiation of vitamin $A$ and $E$ therapy no progression of disturbed visual function could be detected in any patient. These objective tests of retinal function demonstrated that the combined vitamin $\mathrm{A}$ and $\mathrm{E}$ therapy may be useful in arresting retinal deterioration in abetalipoproteinaemia.

The Bassen-Kornzweig syndrome ${ }^{1}$ is a hereditary disorder characterised by gastrointestinal symptoms (steatorrhea), haematological disorders (acanthocytosis), neuromuscular disturbances (ataxia), and retinitis pigmentosa, all appearing in the first decade of life. Early appearance of the retinal disease differs from the hereditary type of isolated retinitis pigmentosa, which appears later, usually during the second or third decade. ${ }^{2}$

The term abetalipoproteinaemia was given to this disease when it was discovered that lipoproteins containing apoprotein $\beta$ are absent from the plasma. $^{3-5}$ Thus the plasma of these patients contains neither chylomicrons nor very low density lipoproteins (VLDL), nor low density lipoproteins (LDL). ${ }^{67}$ Levels of circulating vitamins $A$ and $E$ are very low in all untreated patients. ${ }^{8-11}$ Although the reason for the diminished blood levels of these fatsoluble vitamins is not completely understood, it may be a consequence of faulty absorption and subsequent transport as chylomicrons in the lymph to the liver. ${ }^{12}$ Normally vitamin $A$ is released from the liver bound to retinol-binding protein and is transported to various tissues as a 1:1 molar complex with serum prealbumin. ${ }^{13}$ Vitamin $\mathrm{E}$ is normally transported by Correspondence to Dr S. Bishara, Department of Ophthalmology, Hadassah University Hospital, PO Box 12000 , Jerusalem, Israel. lipoproteins in the plasma. ${ }^{14}$ Vitamin A is necessary for the normal operation of the visual cycle, and vitamin $\mathrm{E}$, normally a component of the photoreceptors, plays an essential role in preventing autooxidation of polyunsaturated fatty acids..$^{15}$

We have followed a group of 8 abetalipoproteinaemic patients who received vitamin $A$ and $E$ in large doses. The purpose of this study was to determine whether supplementation with both vitamins is effective in arresting retinal deterioration.

\section{Patients and methods}

Patients with abetalipoproteinaemia were referred to the Vision Research Laboratory of the Hadassah University Hospital for electrophysiological studies. The diagnosis was based in every case on typical clinical findings, with complete absence of plasma apoprotein $\beta$ as determined by specific radioimmunoassay. In all patients the plasma cholesterol and triglycerides of the parents were normal, a finding that excludes familial homozygous hypobetalipoproteinaemia. ${ }^{12} 17$

The electrophysiological studies included:

Electroretinography (ERG). This was done as described in detail elsewhere.$^{18}$ In short, the patient is placed in a recumbent position in an electrically 
Table 1 Age, treatment, and ocular findings in 8 patients with abetalipoproteinaemia

\begin{tabular}{|c|c|c|c|c|c|c|c|c|c|c|}
\hline \multirow{3}{*}{$\begin{array}{l}\text { Patient } \\
\text { no. }\end{array}$} & \multirow{3}{*}{$\begin{array}{l}\text { Age } \\
\text { (years) }\end{array}$} & \multicolumn{2}{|c|}{ Commencement of treatment } & \multirow{3}{*}{$\begin{array}{l}\text { Fundus } \\
\text { examination }\end{array}$} & \multicolumn{4}{|l|}{$E R G$} & \multicolumn{2}{|l|}{$E O G$} \\
\hline & & \multirow[t]{2}{*}{ Vitamin $A^{*}$} & \multirow[t]{2}{*}{ Vitamin $E^{\dagger}$} & & \multicolumn{2}{|l|}{ First } & \multicolumn{2}{|l|}{ Last } & \multirow[t]{2}{*}{ First } & \multirow[t]{2}{*}{ Last } \\
\hline & & & & & Age & $\begin{array}{l}\text { A wavel } \\
B \text { wave } \ddagger\end{array}$ & $\begin{array}{l}\text { Age } \\
\text { (years) }\end{array}$ & $\begin{array}{l}\text { A wavel } \\
B \text { wave } \ddagger\end{array}$ & & \\
\hline 1 & 1 & At birth & At birth & - & 1 year & $100 / 320$ & 2 & $80 / 300$ & - & - \\
\hline 2 & 3 & $\begin{array}{l}\text { At } 10 \text { days } \\
\text { of age }\end{array}$ & $\begin{array}{l}\text { At } 10 \text { days } \\
\text { of age }\end{array}$ & Normal & 7 months & $70 / 290$ & 3 & Equal & - & - \\
\hline 3 & 5 & At 4 months & At 4 months & Normal & $1^{1 / 2}$ years & $180 / 410$ & 5 & $180 / 400$ & - & - \\
\hline 4 & 4 & At 18 months & At 20 months & Normal & $1 \frac{1}{2}$ years & $90 / 280$ & 4 & $100 / 300$ & - & - \\
\hline 5 & 30 & $\begin{array}{l}\text { At } 26 \text { years } \\
\text { 'irregular' }\end{array}$ & $\begin{array}{l}\text { At } 26 \text { years } \\
\text { 'irregular' }\end{array}$ & $\begin{array}{l}\text { Peripapillary } \\
\text { chorioretinal } \\
\text { atrophy, mild } \\
\text { pigmentation in } \\
\text { macula, narrow } \\
\text { arteries, 'atypical' } \\
\text { retinitis pigmentosa }\end{array}$ & 26 years & $80 / 180$ & 30 & $90 / 200$ & $170 \%$ & $195 \%$ \\
\hline 6 & 21 & At 13 years & At 13 years & $\begin{array}{l}\text { Typical retinitis } \\
\text { pigmentosa }\end{array}$ & 15 years & $15 / 50 \|$ & 21 & $15 / 30$ & $150 \%$ & $165 \%$ \\
\hline 7 & 11 & At 8 years & At 8 years & $\begin{array}{l}\text { 'Inverse' retinitis } \\
\text { pigmentosa }\end{array}$ & 10 years & $150 / 250$ & 11 & $130 / 250$ & - & $165 \%$ \\
\hline 8 & 27 & None\$ & None§ & $\begin{array}{l}\text { Pale disc, narrow } \\
\text { attenuated arteries, } \\
\text { bone corpuscles of } \\
\text { pigment, 'typical' } \\
\text { retinitis pigmentosa }\end{array}$ & 16 years & $15 / 30 \|$ & 27 & Extinct & $120 \%$ & $125 \%$ \\
\hline
\end{tabular}

*50000 U twice a week.

$\dagger 100 \mathrm{mg} / \mathrm{kg} /$ day to a maximum dose of $3000 \mathrm{mg}$ daily.

$\ddagger$ The amplitudes of $\mathrm{A}$ and $\mathrm{B}$ waves are given in $\mu \mathrm{V}$.

$\S$ Vitamin A and B were administered for a few days and stopped after the appearance of bilateral papilloedema.

\|CT measurements.

shielded cell. The pupils are dilated with tropicamide (Mydriaticum) and neosynephrine $10 \%$, after which contact lenses with corneal electrodes (Henke's type) are fixed to both eyes with methylcellulose $2 \%$. Reference electrodes are fastened to the skin above the eyebrow and a ground electrode is attached to one ear. The stimulating light is positioned $20 \mathrm{~cm}$ above and equidistant from both eyes to keep the angle of light comparable to both retinas. The corneal electrodes are connected to the oscilloscope through AC preamplifiers. Thirty minutes are allowed for dark adaptation, and the CT (computer of average transient) is used in cases of very low electroretinograms. With these methods the minimal normal values in our laboratory for adults are $100 \mu \mathrm{V}$ for the $\mathrm{A}$ wave and $400 \mu \mathrm{V}$ for the $\mathrm{B}$ wave amplitudes, with a variability between visits of $20 \mu \mathrm{V}$. In normal children the amplitudes are usually lower.

Electro-oculography (EOG). This was performed in older children and adults by the methods of Arden and Kelsey. ${ }^{19}$ The $180 \%$ light peak/dark trough ratio was considered the lower level of normal.

All patients underwent a routine eye examination including direct and indirect ophthalmoscopy. Blood samples were taken to determine the vitamin $\mathrm{A}$ and $\mathrm{E}$ levels in the serum.

\section{Results}

Table 1 summarises the main clinical and electrophysiological findings in the 8 patients who were included in the study, while Fig. 1 shows serial changes in each patient as detected during the period of follow-up. Three subgroups were noted. The first included 4 children (cases 1-4) who started combined vitamin $A$ and $E$ therapy during the first 2 years of life. ERG values and normal fundus picture did not change till their present ages of 2,3,5, and 4 years respectively. The reduced ERG values of case 4 on his second examination (Fig. 1) were due to technical reasons, as proved by 2 additional examinations. Repeated tests showed serum vitamin E levels to be between $0 \cdot 15$ and $0 \cdot 2 \mu \mathrm{g} / \mathrm{ml}$ (normal range $0 \cdot 5-0 \cdot 8$ $\mu \mathrm{g} / \mathrm{ml})$, or about one-third of the normal values. ${ }^{*}$ Vitamin A levels were between 13 and $45 \mu \mathrm{g} / 100 \mathrm{ml}$ (normal range 15-60 $\mu \mathrm{g} / 100 \mathrm{ml}$ ). (SI conversion: $\mu \mathrm{g} / \mathrm{ml}=\mathrm{mg} / \mathrm{l} ; \mu \mathrm{g} / 100 \mathrm{ml} \times 0 \cdot 01=\mathrm{mg} / \mathrm{dl}$.)

The second subgroup consists of 3 adults (cases 5-7) who started the vitamin $A$ and $E$ treatment later in life, only after electrophysiological functions were already much reduced, and the fundi showed changes of retinitis pigmentosa of different stages of severity. All 3 patients maintained a stable ERG and EOG 


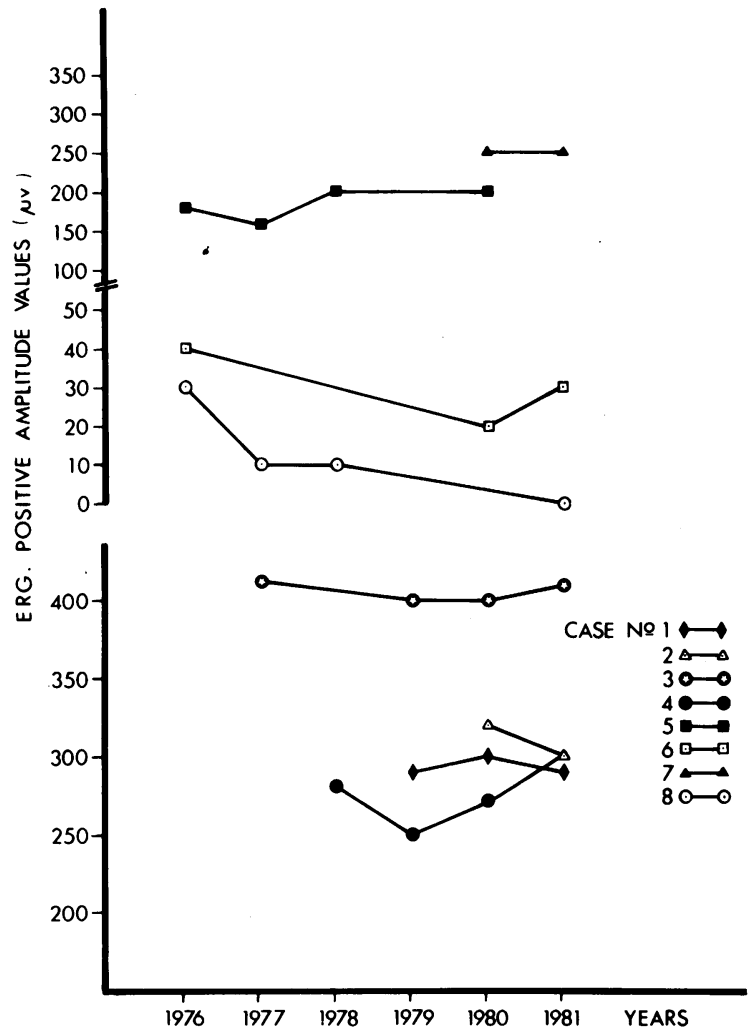

Fig. 1 Serial electroretinogram of $B$ wave amplitudes in patients with abetalipoproteinaemia after initiation of combined vitamin $A$ and $E$ therapy. Patient 8 did not receive sustained therapy.

after initiation of therapy. The vitamin E serum level remains around $0 \cdot 15 \mu \mathrm{g} / \mathrm{ml}$ and vitamin A ranged between 22 and $49 \mu \mathrm{g} / 100 \mathrm{ml}$.

Patient 8 formed a subgroup on her own in that the ERG was reduced and the retinal pathology progressed during the period of observation. However, this patient received treatment for a few days only, stopping after the appearance of bilateral papilloedema, a rare but known complication of vitamin A therapy. Vitamin E levels in the serum of this patient were found to be $0.03 \mu \mathrm{g} / \mathrm{ml}$ only, while that of vitamin A amounted to $22 \mu \mathrm{g} / 100 \mathrm{ml}$.

\footnotetext{
*Because in an abetalipoprotein carrier lipoproteins for vitamin $\mathrm{E}$ are much reduced, only one-third of normal plasma levels can be reached even with optimal therapy. ${ }^{20}$
}

\section{Discussion}

Since Bassen and Kornzweig ${ }^{1}$ reported their first case of abetalipoproteinaemia in 1950 only 36 cases had been described until $1976 .^{9}$ The present study deals with 8 additional patients. The results indicate that in abetalipoproteinaemia combined vitamin $\mathrm{A}$ and $\mathrm{E}$ therapy has a 'stabilising' effect in preventing deterioration both in the fundus and in the electrophysiological functions of the retina. Is this 'stabilising' effect the result of each vitamin acting separately, or is it due to their combined mode of action?

Patients with abetalipoproteinaemia have been treated by vitamin $A^{112122}$ and vitamin E. ${ }^{1020}$ Sperling et al. ${ }^{11}$ claimed that vitamin $\mathrm{A}$ is effective if administered before the retinal changes become irreversible. However, they reported a follow-up for only 3 months. Müller $e t$ al. $^{23}$ described a patient who developed the typical retinal changes at the age of 5 years in spite of being treated with vitamin $A$ and having normal serum levels of this vitamin since the age of 12 months. Similarly Wolff et al. ${ }^{21}$ reported that vitamin A supplementation in their patients did not prevent the development of retinitis pigmentosa. Thus it seems that vitamin A offers only temporary benefit to these patients. The effect of vitamin $E$ was studied by Müller et al. ${ }^{10}$ and Azizi et al. ${ }^{20}$ and a long-lasting beneficial effect was suggested but not proved. ${ }^{12}$

Interrelationships of vitamins $\mathrm{A}$ and $\mathrm{E}$ on retinal structure and histology have recently been demonstrated experimentally by Robinson and coworkers. ${ }^{24}$ While vitamin $\mathrm{A}$ is specifically essential in the visual cycle, vitamin $\mathrm{E}$ is known to have broader functions. It not only protects a variety of cellular membranes-including the retinal photoreceptors-from auto-oxidation, it may in addition serve as an antioxidant for vitamin $\mathrm{A}$ per se. A combined deficiency of both vitamins was shown to accelerate the retinal degeneration in experimental animals, ${ }^{24}$ findings which provide a basis for understanding the possible pathogenesis of the pigmentary retinopathy in untreated patients with abetalipoproteinaemia. Our observations in the 8 patients presented here indicate a synergistic or complementary effect of the 2 vitamins. Accordingly the simultaneous administration of vitamins $A$ and $E$ in patients suffering from abetalipoproteinaemia is advocated.

This study was supported in part by the Lebenson Fund for Ophthalmologic Research (Dr S. Merin) and the Children's Nutritional Disease Project, Canadian Friends of the Hebrew University (Dr RJ. Deckelbaum)

\section{References}

1 Bassen FA, Kornzweig AL. Malformation of the erythrocytes in a case of atypical retinitis pigmentosa. Blood 1950; 5: 381-7.

2 Merin S, Auerbach E. Retinitis pigmentosa (review). Surv Ophthalmol 1976; 20: 303-46.

3 Mabry CC, De George AM, Auerbach VS. Studies concerning the defect in a patient with acanthocytosis. Clin Res 1960; 8: 371.

4 Salt HB, Wolff ON, Lloyd JK, Fosbrooke AS, Camaron AH, Hubble DV. On having no betalipoproteinaemia. A syndrome 
comprising abetalipoproteinaemia, acanthocytosis and steatorrhea. Lancet 1960; ii: 325-9.

5 Druez G, Lamy M, Frezel J, et al. L'acanthocytose: ses rapports avec l'absence congénitale de betalipoproteines. Presse Med 1961; 69: 1546-8.

6 Gotto AM, Phil D, Levy RI, John K, Fredrickson D. On the protein defect in abetalipoproteinemia. N Engl J Med 1971; 284: 813-8.

7 Kayden HJ. Abetalipoproteinemia. Ann Rev Med 1972; 23: 285-96.

8 Campbell DA, Tonks EL. Biochemical findings in human retinitis pigmentosa with particular relation to vitamin A deficiency. Br J Ophthalmol 1962; 46: 151-64.

9 Carr RE. Abetalipoproteinemia and the eye. Birth Defects 1976; 12: 385-99.

10 Müller DPR, Harries JT, Lloyd JK. Vitamin E therapy in abetalipoproteinaemia. Arch Dis Child 1970; 45 : 715.

11 Sperling MA, Hiles DA, Kennerdell JS. Electroretinographic responses following vitamin $\mathrm{A}$ therapy in abetalipoproteinemia. Am J Ophthalmol 1972; 74: 342-51.

12 Herbert PN, Gotto AM, Fredrickson DS. Familial lipoprotein deficiency. In: Stanbury JS, Wyngaarden JB, Fredrickson DS, eds. The Metabolic Basis of Inherited Disease. 4th ed. New York McGraw-Hill, 1978: 544-88.

13 Goodman DS. Vitamin A metabolism. Fed Proc 1980; 39: 2716-22.

14 Bjornson LK, Kayden HJ, Miller E, Moshell AN. The transport of $\alpha$-tocopherol and $\beta$ carotene in human blood. J Lipid Res 1976; 17: $343-52$.
15 Hayes KC. Retinal degeneration in monkeys induced by deficiencies of vitamin E or A. Invest Ophthalmol Visual Sci 1974; 13: 499-510.

16 Katz ML, Stone WL, Dratz EA. Fluorescent pigment accumulation in retinal pigment epithelium of antioxidant-deficient rats. Invest Ophthalmol Visual Sci 1978; 17: 1049-57.

17 Cottrill C, Glueck CJ, Leuba V, Millet F, Puppione D, Brown WV. Familial homozygous hypobetalipoproteinemia. Metabolism 1974; 23: 779-91.

18 Merin S, Shapira Y, Szabo G, Auerbach E. Electro-physiological studies of the visual system in mentally retarded children. $J$ Pediatr Ophthalmol 1973; 10: 217-22.

19 Arden B, Kelsey JH. Changes produced by light in the standing potential of the human eye. J Physiol 1962; 161: 189-204.

20 Azizi E, Zaidman JL, Eshchar J, Szeinberg A. Case report, abetalipoproteinemia treated with parenteral and oral vitamin $\mathbf{A}$ and $\mathrm{E}$ and with medium chain triglycerides. Acta Paediatr Scand 1978; 67: 797-801.

21 Wolff $\mathrm{OH}$, Lloyd JK, Tonks EL. Abetalipoproteinemia with special reference to visual defect. Exp Eye Res 1964; 3: 439-42.

22 Gouras P, Carr RE, Gunkel RD. Retinitis pigmentosa in abetalipoproteinemia: effects of vitamin A. Invest Ophthalmol Visual Sci 1971; 10: 784-93.

23 Müller DPR, Lloyd JK, Bird AC. Long term management of abetalipoproteinaemia: possible role of vitamin E. Arch Dis Child 1977; 52: 209-14.

24 Robinson WG, Kuwabara T, Bierie JG. Deficiencies of vitamin E and $\mathrm{A}$ in the rat: retinal damage and lipofuscin accumulation. Invest Ophthalmol Visual Sci 1980; 19: 1030-7. 